\title{
Impact of the COVID-19 Pandemic on China's Overseas Industrial Zones and the Countermeasures
}

\author{
Haitao Zhou ${ }^{1}$, Zongjian $\mathrm{Wu}^{2, \uparrow}$, Shaobo Yang ${ }^{2, *}$, Tianyu $\mathrm{Hu}^{3, \dagger}$, Haibo Zhou ${ }^{2, \dagger}$, Ting \\ Wan $^{2, \uparrow}$, Zenan Dong ${ }^{4, \dagger}$, Ning Su ${ }^{5, \dagger}$, Chuhong Fan ${ }^{5, \dagger}$, Zhigang Duan ${ }^{6, \dagger}$ \\ ${ }^{1}$ General Manager Office, Hangzhou Sanxi Trading Co.,Ltd, Hangzhou, China. \\ ${ }^{2}$ Research Centre, Shanghai Yice Think Tank, Shanghai, China. \\ ${ }^{3}$ School of Information Engineering, Zhengzhou University, Zhengzhou, China. \\ ${ }^{4}$ Sales Department, Estone SRL, Carrara, Italy. \\ ${ }^{5}$ School of MBA, Zhejiang Gong-Shang University, Hangzhou, China. \\ ${ }^{6}$ General Manager Office, Jinhua JG Tools Manufacturing Co,. Ltd, Jinhua, China. \\ *Corresponding author. Email: ysbhn@163.com \\ ${ }^{\dagger}$ Co-first Authors: These authors have contributed equally to this work
}

\begin{abstract}
As the catalyst to promote industrial development, industrial zones create a new growth point for national economic development in the era of COVID-19 pandemic, and increase the driving force to global economic recovery. The pandemic continues to spread in overseas countries, which has affected the overseas operations of Chinese enterprises to a certain degree. But this will not affect the long-term development trend of overseas industrial zones. The ThaiChina Rayong Industrial Zone has played a key role in promoting Thailand-China economy and trade cooperation, and has made great contributions to Thailand's economic development. It has helped more and more Chinese enterprises settle in Thailand, which further helps Thailand optimize its industrial structure and improve its economic development level, and brings greater impetus to Thailand's economic recovery during the pandemic. However, it shall be noted that China's overseas industrial zones, including the Thai-China Rayong Industrial Zone, cannot slack slightly in terms of pandemic prevention and anti-pandemic. There is still a lot of work to do, and a long way to go.
\end{abstract}

Keywords: Industrial Zones, COVID-19, Long-Term Development, Localization, Thai-China Rayong

\section{INTRODUCTION}

Cross-border M\&A and building overseas factory are considered to be the two major paths for Chinese enterprises to go global, but both paths are full of thorns. Almost every Chinese enterprise that expands overseas markets has its bitterness and tears, but they cannot curb the urge of Chinese enterprises to compete to go out. As more and more Chinese enterprises speed up their pace of going global, investment in building overseas industrial zones has become a new trend. ${ }^{[1]}$

The unprecedented COVID-19 pandemic crisis that the world is experiencing indicates that enhancing the level and capacity of national industrial development is an important strategy for stimulating economic growth and accelerating the development of various industries. How to select, apply, and coordinate policy tools, promote the resumption of production and work, and stimulate the vitality of industrial development urgently need to be discussed and resolved by governments of various countries. ${ }^{[2]}$ As of December 2021, the pandemic has continued to spread around the world, and the deterioration speed in some countries has exceeded expectations. However, China has taken the lead in controlling the pandemic and has steadily resumed work, production, business and markets, which reflects the resilience of its industry and economy and the effectiveness of policies. Under the background of the global economy of being affected by the COVID-19 pandemic, what changes will occur in the development of overseas industrial zones? What opportunities will it encounter in the future? 


\section{IMPACT OF THE COVID-19 PANDEMIC ON CHINA'S OVERSEAS INDUSTRIAL ZONES}

UNIDO studied the experiences of countries at different stages of industrialization in formulating and applying industrial policies, and summarized 10 policy tools that can effectively promote national industrial development. Among them, practice has proved that building industrial zones is a practical and effective way to promote domestic industrial production and develop foreign trade. It works with other policy tools, including foreign investment incentive policies and export policies, to promote the development level of a country's industrialization. As the catalyst to promote industrial development, industrial zones create a new growth point for national economic development in the era of COVID19 pandemic, and increase the driving force to global economic recovery.

Being one of the most productive countries in promoting industrialization, China is a model for building industrial zones to promote industrial development. ${ }^{[3]}$ In the past four decades, China has successfully built and operated various types of industrial zones in China and overseas, solved major problems in zone development such as attracting investment, infrastructure construction, and coordination of policies $\&$ measures, and accumulated abundant experience.

From investment in building overseas factories for single enterprise to collectively building overseas factories in the form of industrial zones, Chinese enterprises have undergone a strategy upgrading of "going global". The Chinese overseas industrial zones were initially launched by enterprises to function as production and trade bases for themselves. ${ }^{[4]} \mathrm{As}$ early as 2000, Haier established an industrial zone in the United States; in 2004, Tianjin Free Trade Zone Investment Holding Group Co., Ltd. established the Tianjin American Commercial Industrial Zone in South Carolina. Since 2006, the Ministry of Commerce of the People's Republic of China has listed promoting the construction of overseas economy and trade cooperation zones as a key project. The overseas zones built by enterprises are no longer limited to serve for themselves only, but on a large scale to attract secondary developers engaged in manufacturing and trading activities to settle in the zones. With the rise in the overall cost of China's domestic manufacturing industry and the demand for enterprises to expand the international market, go global has become an inevitable trend for China's manufacturing industry. On the other hand, directly building overseas factories can bypass some trade barriers to domestic products and enter the markets of developed countries more conveniently. Currently, there are nearly hundreds of overseas zones built by Chinese enterprises throughout the world. These zones include various economy and trade cooperation areas such as industrial zones and technology industrial zones, but most of them are industrial zones.

What are the advantages of China in the building overseas industrial zones? First, China has very rich experience in building domestic industrial zones. Therefore, these successful experiences can be copied overseas relatively easily. In fact, many well-developed domestic industrial zones in China have successfully copied their experience to overseas industrial zones. Second, the support of China's national policies. The Chinese government has actively strengthened policy communication and signed relevant cooperation documents with overseas countries, especially countries along the "Belt and Road". This has cleared policy obstacles and reduced the policy risks for enterprises to invest in overseas industrial zones. Third, China possesses a very complete industrial ecology of chain agglomeration, especially the obvious advantages in manufacturing industry. Promoting the transfer of some production capacity through overseas industrial zone will increase the resilience of the supply chain on the one hand, and on the other hand, it will make it easier to open up overseas markets.

The pandemic continues to spread in overseas countries, which has affected the overseas operations of Chinese enterprises to a certain degree. But this will not affect the long-term development trend of overseas industrial zones. Overseas industrial zones have a strong agglomeration effect of industrial chain, and the supporting facilities are relatively complete. Owing to the high level of cooperation, they can obtain some auxiliary preferential policies from the host country, and their future development prospects are still optimistic. Overseas industrial zones are often located close to the origin of raw materials, and the upstream and downstream enterprises in the industrial chain are relatively concentrated, which is beneficial for enterprises to control supply chain risks and also reduces the transportation costs. For example, on March 18, 2021, Belarus's first enterprise of traditional Chinese medicine project settled in Great Stone Industrial Park. In the postpandemic era, facing the restructuring of the global industrial chain, overseas industrial zones will be of higher strategic significance in balancing regional economic development, optimizing the industrial layout of Chinese enterprises, and diversifying the supply chain risks.

Nevertheless, in view of the global pandemic trend, the pandemic will still last for some time. Even the pandemic prevention is adequate and the vaccine is properly vaccinated, there is no $100 \%$ guarantee that people will not be infected. In the long run, in addition to the virus itself, the unemployment problem caused by the pandemic, the economic predicament, and the intensified conflict between the government and the people will be more troublesome challenges for the host country where 
the overseas industrial zones are located. If they cannot be resolved, they will have a long-term impact on the development of the host country.

\section{COUNTERMEASURES TO THE COVID- 19 PANDEMIC OF CHINA'S OVERSEAS INDUSTRIAL ZONES: CASE OF THAI- CHINA RAYONG INDUSTRIAL ZONE}

Thai-China Rayong Industrial Zone is a modern industrial zone developed by China Holley Group in Thailand for Chinese investors. Founded in 1970, Holley Group is a private enterprise group with Holley Group Co., Ltd. as its parent, medicine as its core business, and diversified investment development. Holley has repeatedly been selected as one of the top 500 Chinese enterprises, the top 500 national large enterprise groups, and the top 500 Chinese private enterprises, and is a model enterprise for the "Belt and Road" construction. The development of Thai-China Rayong Industrial Zone was started in 2005 and it has been listed as the first batch of overseas economy and trade cooperation zones. ThaiChina Rayong Industrial Zone is located on the eastern coast of Thailand, close to the capital Bangkok and Laem Chabang deep-water port. Currently, it has formed a wellknown and influential Chinese overseas economy and trade cooperation zone in Thailand, and has become the largest industrial cluster centre and manufacturing export base for traditional Chinese competitive industries in Thailand and ASEAN. The overall planned area of the zone is $12 \mathrm{~km}^{2}$. The main industry orientation of the zone involves Chinese enterprises in automobile and motorcycle and their parts, new energy, new materials, machinery, electronics, and hardware. It consists of general industrial area, bonded area, logistics \& storage area and commercial living area. The goal of the zone is to build an industrial cluster centre and manufacturing export base for traditional Chinese competitive industries in Thailand, and eventually form a modern comprehensive zone integrating manufacturing, exhibition, logistics and commercial living areas. ${ }^{[5]}$

Thailand is one of the countries to first confirm case of the COVID-19. Since the first case was found in early 2020, Thailand has experienced two waves of pandemics. The first wave was in March and April 2020, with the peak of daily confirmed cases of about 300 people. However, the first wave of pandemic was successfully contained under the strict control measures adopted by the Thai government of prohibiting the external entry and restricting the internal movement of people. The second wave of pandemic broke out at the end of February 2021, and the source was a concentrated area of foreign workers. Although the peak of daily confirmed cases exceeded 1,000 people, the pandemic was mainly confined to Samut Sakhon near Bangkok. The Thai government has taken stricter containment measures against the pandemic centre, and the pandemic has been effectively controlled.
It did not spread, and the pandemic centre also began to calm down in late March. Just when the Thai people were ready to celebrate the New Year, a new wave of pandemic hit them unexpectedly, leaving no time for respite. Even more worrisome, compared with the previous two waves, this wave of pandemic is more fierce and has brought the most severe challenge to Thailand's pandemic prevention and control so far. In order to restrain the third wave, the government has taken pandemic prevention measures, such as access control, banning dinning in restaurants, closing department stores, and even imposing a curfew. But the third wave of the pandemic were not restrained. According to the latest news from the Thailand Pandemic Control Centre on November 24, 2021, there has been a total of 2,081,992 confirmed cases and 20,544 deaths since the outbreak. Thailand can be considered to have pulled through the 2020 pandemic successfully. The 2021 fight against mutant viruses, especially Delta, was really a hard battle. Optimistically, even if there are no new viruses, it will be after mid-2022 at the earliest.

At the tough time of China's fight against the pandemic, Thailand actively donated medical supplies to China, and all sectors of the Thai society expressed their support for the Chinese people's fight against the pandemic in various ways. After the outbreak in Thailand, China promptly gave a hand to Thailand, shared its antipandemic experience, and provided urgently needed medical supplies. China and Thailand helped each other and fought side by side, which further sublimated their traditional friendship. By 2021, China has been Thailand's largest trading partner for seven consecutive years, and by 2019 it has become Thailand's largest source of foreign investment. In recent years, the Thai government has vigorously promoted the construction of "Thailand 4.0" and "Eastern Economic Corridor", and strengthened the docking with the joint construction of the "Belt and Road". The two sides actively promote cooperation in innovative sectors such as e-commerce, and the China-Thailand comprehensive strategic partnership has been continuously developed.

As of December 2021, most of the enterprises in the Thai-China Rayong Industrial Zone have continued their normal production under the premise of strict pandemic prevention. Many Chinese-funded enterprises have realized localized operations, and Chinese employees in the zone account for only $10 \%$. The production in the zone is basically unaffected, and normal operations are maintained. As an important platform for the joint construction of the "Belt and Road" capacity cooperation, as of August 2021, the Thai-China Rayong Industrial Zone has attracted 167 Chinese-funded enterprises, with a cumulative industrial output value over USD 16 billion. The Thai-China Rayong Industrial Zone has played a key role in promoting Thailand-China economy and trade cooperation, and has made great contributions to Thailand's economic development. It has helped more and more Chinese enterprises settle in Thailand, which 
further helps Thailand optimize its industrial structure and improve its economic development level, and brings greater impetus to Thailand's economic recovery during the pandemic.

With the support of all-level governments of China and Thailand and in the context of accelerating "going global" for Chinese enterprises, Thailand's good investment environment and high-quality services in the zone have made the Thai-China Rayong Industrial Zone one of the well-developed cooperation zones among China's overseas economy and trade cooperation zones. Nevertheless, there are still some problems in the zone, such as the contradiction between the China speed and the slow-pace work efficiency in Thailand, difficulty of zone enterprises in adapting to the adjustment of Thailand's preferential policies, the lack of professional talents in electromechanical, factory and accounting, especially those who can speak both Chinese and Thai, and education bottleneck of the Chinese employees and their children in the zone. ${ }^{[6]}$

As of December 2021, in addition to India, Malaysia, Philippines, Vietnam, Thailand and other Asian countries are also suffering new impacts from the COVID-19 pandemic. As key production and manufacturing bases of the global market, the pandemic in these places continues to ferment, which will have an impact on the global supply chain. In this overall context, localization is one of the sustainable development paths of overseas industrial zones. Realizing the localization of overseas industrial zones is a significant symbol of creating people-to-people bonds and building a "community with a shared future." Enterprise investment in building local factories are not only a process for the enterprise to achieve product production \& sales and technology transfer, but also to build supporting facilities for living, solve the living problems of enterprise employees, strengthen the local connections, and organize social welfare activities to feed back to and benefit the local community. The Thai-China Rayong Industrial Zone has been focusing on the localization of enterprises for many years. The products from the zone enterprises not only meet the demands of the Thai market, but the zone itself has also become a window for technical exchanges, which expands many advanced Chinese products and technologies to various places of Thailand, improves the technical level of related industries in Thailand, and promotes the economic and social development of Thailand.

Under the impact of the COVID-19 pandemic, the business of China's overseas industrial zones is facing challenges, but the competitiveness of overseas industrial zones with high degree of globalization has also begun to become prominent. Facing the complex situation in the future, the Thai-China Rayong Industrial Zone needs to further strengthen the integration of overseas and domestic and gather all forces to realize the localization of the Thai-China Rayong Industrial Zone, and actively dock with the Thailand 4.0 strategy, conform to the Thai strategic planning, and achieve common development.

\section{CONCLUSION}

The sudden COVID-19 pandemic has hindered the resumption of work for many enterprises around the world in the short term, and their production activities have stalled. ${ }^{[7]}$ These difficulties will be passed on to the industrial zones, which are the carriers of regional economic development. So, what impact will this have on China's overseas industrial zones? How should the zone respond? Affected by the COVID-19 pandemic, enterprises in overseas industrial zones have an outstanding problem of resuming work, and many host countries' industrial development has fallen into a slow or even stagnant state. As an important carrier for the industrial development of the host country, it is of vital importance for overseas industrial zones to prevent and control the pandemic and achieve stable development under the current situation. In the pandemic crisis, overseas industrial zones showed a large gap in response speed, strength, and innovation. The pandemic prevention and control efficiency and effectiveness of Thai-China Rayong Industrial Zone are relatively prominent, and the localization of specific measures has been accelerated to turn "danger" into "opportunity." However, it shall be noted that China's overseas industrial zones, including the Thai-China Rayong Industrial Zone, cannot slack slightly in terms of pandemic prevention and anti-pandemic. There is still a lot of work to do, and a long way to go.

\section{ACKNOWLEDGMENTS}

This work was supported by the Major Program of the National Social Science Foundation of China [grant number 20\&ZD124], the National Social Science Foundation of China [grant number 21CJY024, 20BJL040, 19BJL108, 19BJL185], the National Natural Science Foundation of China [grant numbers 71773115 , 72174180, 72074195, 71973129, 72072162, 72173073, 51774013, 71503003], the Philosophy and Social Science Program of Zhejiang [grant numbers 22NDQN290YB, 22QNYC13ZD, 21NDYD097Z], the Humanity and Social Science Foundation of Ministry of Education of China [grant numbers 21YJA790043, 21YJA630037, 19YJA790107, 19YJA630092, 18YJA790088, 21YJCZH213].

\section{REFERENCES}

[1] Liu B, Lin C. Research on Sino-foreign cooperative construction of overseas industrial clusters. Scientific Management Research, 2019 (2), pp.166170. 
[2] Li S-J, Sun B, Hou D-X, Jin W-J and Ji Y, Does Industrial Agglomeration or Foreign Direct Investment Matter for Environment Pollution of Public Health? Evidence From China. Front. Public Health,2021,9:711033,pp.1-14.

[3] Hu F, Xi X, Zhang Y, Influencing mechanism of reverse knowledge spillover on investment enterprises' technological progress: An empirical examination of Chinese firms. Technological Forecasting \& Social Change, 2021,169: 120797, pp.1-10.

[4] Meng G, Yang K, Zhu F, Hainan of China: The evolution from a special economic zone to a comprehensive and compound free trade port. Geographical Research, 2018 (12), pp.2363-2382.

[5] Tao Y, Xiang L, Yu R, “Aircraft Carrier" model for Chinese enterprise overseas operation: A case study of Thai-China Rayong Industrial Zone. Journal of Business Economics, 2019(7), pp. 39-49.

[6] Meng G et al., 'Sub-Zone' Model and Benefit Evaluation of Thai-Chinese Rayong Industrial Zone. Scientia Geographica Sinica,2020 (11), pp.18031811.

[7] Xi X, Wei S, Lin K-L, Zhou H, Wang K,Zhou H, Li Z,Nan N, Qiu L, Hu F, Tsai F-S and Chen D, Digital Technology, Knowledge Level, and Food Safety Governance: Implications for National Healthcare System. Front. Public Health,2021, 9:753950, pp.110 